\title{
1920'lerin Ankara'sından Bir Mahallenin ve Konutlarının Anlattıkları
}

\author{
Deniz Avc1 Hosanl1 ${ }^{1}$ \\ ORCID: 0000-0003-1157-5654
}

Öz

Şehirlerde tarihi izlerin, yani geçmişi yeniden inşa etmek için gerekenlerin kalmadığı bir yapısal çevreyi hayal etmek acı vermektedir. Fakat, günümüzde şehirlerin hızla büyümesiyle birlikte tarihi kent merkezleri yeni inşa edilen bölgelerin arasında kalmış, unutulmuş ve terk edilmiş, dolayısıyla yapısal çevrenin bütünlüğ̈̈ zarar görmüş̧ür. Varlıklarım devam ettirmekte olan eski yapılar, sahiplerinin taleplerine zaman geçtikçe cevap vermekte yetersiz kalmış ve bundan dolayı el değiştirmiş; yeni kullanıcıları tarafindan bu yapılara zarar veren yeni işlevlerle kullanılmışlardır. Oysa tarihi yapılar, bölgesel, yapısal ve mekânsal ölçekte, sokakla ve birbirleriyle kurdukları ilişkilerle mahallenin dönemsel kullanım özelliklerini yansıtarak, geçmişteki gündelik hayata ışık tutmakta ve mahallenin ruhunu yansitmaktadır. Bu makalede Ankara'nın başkent olmasıyla birlikte 1920'lerde yeniden inşa edilmiş olan Hisarönü Mahallesi ile müstakil ev ve apartmanlarının anlattıkları üzerinde incelemeler yapılmış; geçmişten aktarılan izlerle birlikte, günümüzdeki kullanımları analiz edilmiş; güncel kullanımın izlere verdiği zararlar tartışılmıştır. Ankara'da 1920'lerdeki mahalle dokusunu hala bütüncül olarak okuyabileceğimiz tek bölge olan Hisarönü Mahallesi'nde bulunan ve günümüzde yıkıma karşı direnen konutların tarihsel ve güncel anlatımlarının okunması sonucu koruma tartışmaları yapılmıştır.

Anahtar Kelimeler: Tarihi kent merkezi, Erken Cumhuriyet Dönemi, Hisarönü Mahallesi, konut, tarihsel anlatım, kültürel mirası koruma

\footnotetext{
${ }^{1}$ Dr., İhsan Doğramacı Bilkent Üniversitesi, E-mail: denizavcihosanli@gmail.com idealkent (c) Kent Araştırmaları Dergisi (Journal of Urban Studies) 


\title{
Narrative of a Neighborhood and its Housing from the 1920s' Ankara
}

\author{
Deniz Avc1 Hosanl12 \\ ORCID: 0000-0003-1157-5654
}

\begin{abstract}
It is heart breaking to imagine a built environment without the historic traces in the cities, i.e. the necessary clues to reimagine the historic environment. Unfortunately, with rapid growth of the cities, the historic environment loses its traces as the historic city centers are trapped among the newly built areas, forgotten and abandoned because the historic buildings no longer meet the requirements of their owners, thus the new users reutilize them with incompatible functions. However, the historic buildings in their regional, structural and spatial contexts display the characteristics of the daily life and spirit of a neighborhood from a certain time and place. Consequently, this article studied the single-family houses and apartments built during the 1920s in the Hisarönü Neighborhood - which was entirely reconstructed as Ankara became the new capital city - with an analysis on the historic and current narrative of the neighborhood demonstrating the danger of the current unconscious usage. As the Hisarönü Neigborhood is the only remaining neighborhood from the 1920s' Ankara in its integrity, this study focused on the silent story told by its residential architecture resisting to demolition and used these to consolidate the conservation arguments.
\end{abstract}

Keywords: Historic city centers, Early Republican Period, Hisarönü Neighborhood, housing, narrative of historic buildings, conservation of cultural heritage

2 Dr., İhsan Doğramacı Bilkent University, E-mail: denizavcihosanli@gmail.com

idealkent (c) Kent Araştırmaları Dergisi (Journal of Urban Studies)

http://idealkentdergisi.com

Geliş Tarihi Received Date: 15.19.2020 Kabul Tarihi Accepted Date: 14.12.2020 


\section{Giriș}

Farklı disiplinler kendi alanlarına yönelik 'söylem'ler üretmektedirler ve bu çeşitlilik 'söylem' kavramına net bir tanım konulmasına olanak vermez; bu kavramı tam olarak tanımlamak, kullanıldığı çok çeşitli yollar nedeniyle imkansizdır (Abu-Lughod ve Lutz, 1990, s.7; Sawyer, 2002, s.434). 'Söylem' çalişmalarında 'dil' anahtar kavram olarak kabul edilse de, tek etken olarak değerlendirilemez, 'söylem'lerin oluşmasında belli başlı simgeler ve izler de rol oynamaktadır (Basa, 2000, s.15-16). 'Söylem', sözlü ve yazılı sözlerin üretimi olduğu kadar bunların tamamının bir sosyal grup tarafından uzun vadede yeniden üretimi olarak da tanımlanabilir (Rey, 1995, s. 168; Basa, 2000, s.19). Uzun vadede yeniden, tekrar ve tekrar üretilen ise sadece dil değildir.

'Söylem' ve 'dil' üzerine yapılan tüm çalışmalar, dil kullanımının her alanda kendi aracı ve amacı olduğundan bahsetmekte, ve 'dil' ile olan anlatımların tek başına yeterli olmadığını vurgulamaktadır. Mimarlık ve şehir planlama alanları ise, anlatımların sadece dil ile olmadığını ve yapılı çevre ile de olabileceğini göstermektedir; çünkü yapılı çevrede insan yapısı olan her öğenin kendi anlatımları vardır. Bu anlatımlar belirli bir zamana ve mekâna aittir, ve yukarıdaki açıklamada belirtildiği gibi şahıslar ve sosyal gruplar tarafından uzun vadeye yayılarak tekrar ve tekrar üretilirler. Bu tekrar üretim, o mekânın hafızasını ve ruhunu değiştirmez, aksine ona süreklilik sağlar. Nora (2006, s.17-19), hafızanın, yaşanan gruplar tarafından sürekli üretilen (ve yeniden üretilen) yaşamın kendisi olduğundan, bu süreklilik duygusunun kökünün ise mekânda olduğundan bahseder. Yani mekânları kullanıc1lar yaşantılarıyla tanımlamakta ve anlamlandırmaktadır. Yapılı çevreye kullanıcıları tarafından yapılan her müdahale bu hafızanın sürekliliğini sağlamaktadır.

Kent, yapılar topluluğu, mahalleler, yapılar ve hatta yapıların iç mekânları, toplumsal düzen ve bu düzenin devam etmekte olduğu süreçlerin doğası hakkında birçok işaret vermektedir; yani denilebilir ki kentler her tür işaret ve simgeyi içermektedir ve halk bunlara belli başlı anlamlar yüklemektedir (Harvey, 2006, s.35-37). Kent içinde mahallelerin ve kullanıcılarının arasında ise kendilerine özgü diyalektik oluşmaktadır; bunlar, şahısların çevreleriyle kurdukları içeri ve dışarı (giriş/çıkış, içerisi/dışarısı, mimarlık söyleminde basitleştirmeler, bknz. Basa, 2000, s.144-146) arasındaki varoluşsal diyalektik ve sosyal düzeyde kullanıcının başka kullanıcılarla kurduğu sosyal

\footnotetext{
${ }^{3}$ Standart kullanımda söylem, bir cümleden daha büyük bir dil birimine atıfta bulunur ve söylem analizi, bu cümle dizilerinin incelenmesidir (Sawyer, 2002, s.434).
} 
diyalektik olarak tanımlanabilir (Mayol, 2009, s.35). Burada 'içeri' olarak tanımlanan konut iken 'dışarı' olarak tanımlanan kentsel uzamdır. Mahalle ise gitgide 'içerisi'nin bir uzantısı haline gelmeye başlamıştır; yani kullanıcı için mahalle, en mahrem olanla (ev/hane) en bilinmeyen olanın (kentin tamamı) arasındaki bağdır (Mayol, 2009, s.35). Bu nedenlerden dolayı bir mahallenin kullanıcısıyla kurduğu bağ özel bir bağdır, özel uzamı kamusal uzamdan ayıran bir sinır yaratmaktadır.

Harvey (2006, s.35-37), kentte mekânın süregelen şekillendirme sürecinden bahsederken, bu sürecin, bir toplumun kültürünü, geçmiş ve mevcut toplumsal düzenini, o toplumun amaçlarını, ihtiyaçlarını ve hatta korkularını simgelediğinden bahsetmektedir; yani kent sakinlerinin kendilerini çevreleyen mekâna karşı takındıkları tavır önem kazanmaktadır (Harvey, 2006, s.3537). Mahalle ve sakinleri arasında kurulan bağ (olumlu tepki, gösterilen tavır), mekânın ruhunu oluşturmakta, kişilerin, toplulukların hafızalarında özel bir yer tutmaktadır. Nora (2006, s.31-32), hafıza mekânlarının, kelimenin maddi, sembolik ve işlevsel olmak üzere üç anlamını da içerdiğinden bahsetmektedir. Dolayısıyla somut görünümlü mekân ancak hayalgücü ona sembolik bir anlam verdiğinde hafıza mekânı haline gelmektedir. Mahalle sakinlerinin yaşadıkları mahalleye verdiği sembolik anlam "bir toprağa/mekâna ait olma" duygusudur. Fakat Harvey'e (2006, s.40) göre hafıza zayıflayabilir ve mekânsal imgenin güçlendirilmemiş parçaları kaybolabilir. Bundan dolayı toplumsal mekân sadece bireyden bireye ve gruptan gruba değil, zamana göre de değişir; hafızanın kaybolmasıyla özgün anlatım da anlam kaybına uğrayabilir.

Günümüzde gitgide metropolleşme sürecinde olan büyük şehirlerde, 'eskimekte' olan ve çağdaş yaşamın hızlıca ürettiği yeni yerleşim bölgelerinin ve yapılarının sağladığı şartları karşılayamayan eski yerleşim bölgeleri, özellikle tarihi konut bölgeleri, yani ‘mahalleler' terkedilmektedir. Bu eski yerleşim bölgeleri 19. yüzyıl sonu ile 20. yüzyıl başında modernleşen şehirlerin ilk yerleşim bölgeleridir ve bundan dolayı günümüzde tarihi kent merkezlerinde (veya yakınında) konumlanmakta ve bu konumdan dolayı ticari olarak yeniden işlevlendirilmektedir.

Günümüzde karşılaşılan diğer bir problem ise ticaret kavramının 20. yüzyıla göre değişmiş olmasıdır. Bu değişimle birlikte, 20. yüzyıl boyunca kent merkezlerinde ticari amaçlı kullanılmakta olan eski yerleşim bölgeleri, ticaretin yeni AVM'lere taşınmış olmasından kaynaklı olarak bu işlevlerini de yitirmeye başlamış ve terk edilme sürecine girmişlerdir. Sonuç olarak özgün hafızalarını yitirmiş olmakla kalmayıp, kullanımda kalmalarıyla geçmişle 
bağ kuran hafızalarını da kaybetmeye başlamışlardır. Bu çalışmanın incelemekte olduğu mahalle, bu süreci yaşamaya devam eden bir mahalledir.

Hisarönü Mahallesi, Ankara'nın 1923 yılında Cumhuriyet' in yeni başkenti olmasından sonra eski tarihi kent merkezinde, 1916 yılında çıkan yıkıcı bir yangının bıraktığı boş alan kullanılarak, yani yitik olan bir hafıza mekânı üzerine yeni bir hafıza mekânı oluşturularak yeniden inşa edilmiş bir mahalledir (Şekil 1). Yitik olan hafıza mekânı, Ankara'nın Cumhuriyet öncesi Ermeni ve Rum nüfusu tarafından kullanılan mahallesine aittir. Bu mahallenin yeni müstakil ev ve apartmanlarıla birlikte 1920'lerde yeniden inşası, döneminin kentsel planlama uygulamalarından yapıların inşa tekniklerine, konutların mekânsal dönüşümlerinden aile yapılarındaki dönüşüme ve komşuluk ilişkilerindeki değişimlere kadar modernleşen yeni bir ulus devlet kurma politikalarının başarmak istediği tüm yenilikleri uygulayarak gerçekleşmiştir.

Bu mahallenin seçiminde etken olan bir başka faktör ise son dönemlerde izlenmiş olan yanlış kentsel dönüşüm politikalarından dolayı Ankara'nın 1920'ler döneminde inşa edilmiş yerleşim bölgeleri arasında günümüzde mahalle olarak yapısal bütünlügünü koruyan tek bölge olarak kalmış olmasıdır. Fakat çağdaşlarının yaşamış olduğu sonla yüzleşmektedir; yani mahalle kavramı yitecek ve geriye özgün bağlamından koparılmış bir iki örnek kalacaktir.

1920'lerde eskinin içinde yeninin sergilendiği Hisarönü Mahallesi, günümüzde Halbwachs'ın (2017, s.61) tanımladığ tarihi olan bölgeyi yeni olandan ayıran net çizgilerin olmadığı bir mahalle haline gelmiştir. Oysa geçmiş ve tarih mahallenin içinde hala varlığını sürdürmektedir ve bu tarihi bize o mahallenin yapıları ve duvarları anlatmaktadır. Bu makalede, Hisarönü Mahallesi'nin ve 1920'lere ait konutlarının, inşa edildikleri dönemdeki gündelik hayata ve günümüzdeki kullanımlarına dair anlattıkları üzerinden koruma yaklaşımları tartışılmaktadır. Bu tartışmalarda insanların tutkuları ve enerjileriyle var olan şehirlere ve yapılara organizmalar olarak yaklaşılmakta, yani insan, şehir ve yapılar arasında analoji yapılarak (Colean, 1953, s.9) tarihi bölgenin ve yapılarının dili incelenmektedir. ${ }^{4}$

\footnotetext{
${ }^{4}$ Lefebvre (2010, s.138) sormaktadır: “'İnsan’ı tanımlamayı bilseydik, kenti ve şehri tanımlayamaz mıydık? ...Tabii eğer durum tersi değilse; içinde barınmak ya da kaçmak için siteyi inşa eden bu politik hayvanı tanımlamak için önce şehri tanımak gerekmiyorsa?"
} 


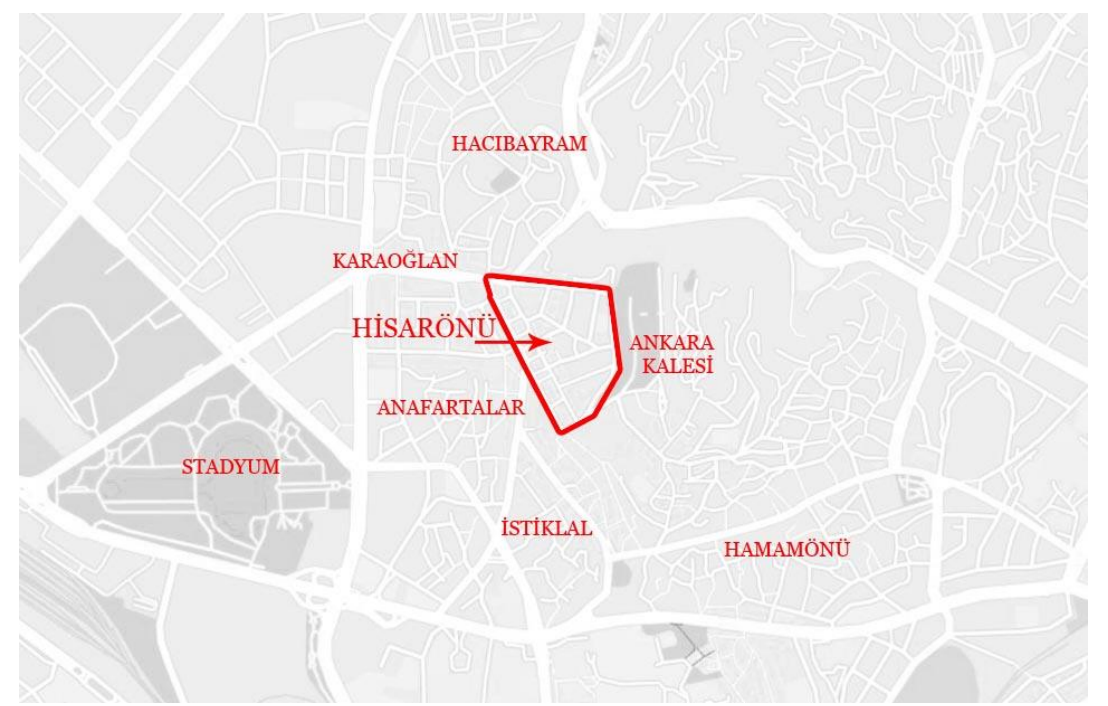

Şekil 1. Hisarönü Mahallesi'nin Konumu (Arka plan Kaynak: Snazzy Maps, 2020).

\section{Ankara'nın Başkent Olarak Yeniden İnşası ve '1916 Yangın' Bölgesinde Yeni Bir Mahalle}

1916 yılının Ağustos ayında Ankara'nın dörtte üçünü yakıp kül eden bir yangının Hisarönü veya Karay'ın ifadesiyle Hisardibi'nde (Karay, 1921; Birinci, 2009, s.131) Ankara'nın en güzel evlerinin olduğu Ermeni ve Rum mahallelerini yok ettiği sıkça dile getirilmiştir (Şahin Güçhan, 2001, s.149). Savaştan bitap düşmüş Ankara 1923 yılında başkent olunca, İstanbul'dan gelen yönetici sınıfı kasvetli, bakımsız ve kurak olan iç karartıcı bir şehirle karşılaşmışlardır (Akgün, 2000, s.222). Üstüne üstlük Ankara'nın en rahat otelleri de Ermeniler ve Rumlar tarafından işletildiği için aynı yangında yok olmuştur (Karay, 1921; Birinci, 2009).

Kurtuluş Savaşı (1919-1922) sırasında Milli Mücadele'nin merkezi olan Ankara, şüphesiz ki 1923 yılında Cumhuriyet'in ilanıyla birlikte başkent statüsüne erişerek ödüllendirilmiştir. Ankara, tüm kamu kuruluşlarının ve özel firmaların çalışanlarının yeni başkente gelmesiyle hızlı bir göçe tanık olmuştur. Üstelik Anadolu'nun dört bir yanından inşaat sektöründe ve hizmet sektöründe çalışmak için işçiler de Ankara'ya akın etmiştir. Tüm bu göçleri kaldıramayan Ankara'da barınma problemi kentin tüm yeni gelenlerine bir süre mahrumiyet yaşatmıştır. Devlet yönetiminin ve Belediye'nin (Şehremaneti) girişimleriyle Ankara'nın tarihi kent merkezi için 1924'de Dr. Carl Christoph Lörcher'den yeni bir plan istenmiş, uygulamasında problemler çıkınca ve ye- 
tersiz kalınca tarihi kent merkezinin güneyinde kalan Yenişehir bölgesi istimlak edilmiş (Sarığlu, 2001, s.38) ve Lörcher 1925 yılında Yenişehir planını hazırlamıştır (Sarıŏlu, 2001, s.49; Cengizkan, 2004).

Ankara tüm olumsuzluklarına ve yetersizliklerine rağmen yeni bir başkent kurma çabalarında fiziksel ve ideolojik projenin gerçekleşmesi için elverişli bir konuma sahiptir. Nüfusu İstanbul'a göre homojen (Tekeli, 2006, s.7) ve konumu Anadolu'ya modernleşme konusunda örnek olacak şekilde merkezidir. En önemlisi Ankaralılar' ın Kurtuluş Savaşı davasına olan katkılarından dolayı kent ve yönetim arasında vefa bağı oluşmuştur (Şenol-Cantek, 2011, s.83-84). Ankara'yı başkent olarak ideal kılan en önemli özellik ise kentsel gelişim için ve modern bir başkentin sıfırdan yaratılma projesi için uygun özelliklere sahip olmasıdır.

Ankara'yı modern bir başkent haline getirmek için ilk girişim belediyenin kurulmasıdır. Belediyenin sokak sağlıklaştırma, altyapı ve fabrikalar oluşturma girişimlerinin yanı sıra (Şenol-Cantek, 2011, s.106-107), en önemli projesi Ankara'nın göçlerle birlikte artan nüfusunu barındırmak için konut üretimidir. Lörcher planlarının uygulanması esnasında ise tarihi kent merkezinin yetersiz kaldığ ve zaten konut üretiminin de rastgele devam ettiği görülecektir. Lörcher tarihi kent merkezinin büyük bir kısmının yeniden inşa edilmesini önermiş ve devlet bu fikri uygulamamış, sadece önerilen aksları dikkate almıştır (Tankut, 2000, s.303). Korumacı yaklaşımdan daha çok maddi kaynaksızlık sonucu Lörcher'in eski şehir planının uygulanmadığı bilinmektedir. Bilinçli bir koruma yerine, kaderine terk edilen tarihi kent merkezi varlığını devam ettirmiştir. Belediye ve yönetim kaynaklarının büyük bir kısmı ise Yenişehir'i inşa etmek için kullanılmıştır.

Tarihi kent merkezinde bulunan, 1916 yangını sonucu boş arazi olarak kalan Hisarönü Mahallesi ise yeniden yapılaşma için önemli bir fırsat olarak görülmüş olmalıdır. Hisar ve Anafartalar Caddelerinin açılması ve ana akslara dönüştürülmesiyle, bu iki cadde ve kale arasında kalmış olan bölge Lörcher'in planına göre şekillenmiştir (Aktüre, 2000, s.59). Bu bölgede yangından hemen sonra ve özellikle Cumhuriyet'in ilk yıllarında döneminin biçimsel, yapısal ve mekânsal karakterini taşıyan birçok müstakil ev ve apartman inşa edilmiştir. Ticari aks olan Anafartalar Caddesi'ne ve devlet kurumlarının Yenişehir'de Vekaletler/Bakanlıklar Mahallesi kurulmadan önce bulunduğu Karaoğlan Mahallesi ve Hükümet Meydanı'na yakınlığıyla, Hisarönü Mahallesi'nin yangın öncesi prestijli konumunu yeni ev ve apartmanlarla devam ettirdiği düşünülmektedir. 


\section{Mahalle'nin Sosyoekonomik Statüsü ve Orta Sınıfın İkilemi: Ulus'un Apartmanları mı Yenişehir'in Evleri mi?}

Kuşaktan kuşağa değişen fikirler ve ihtiyaçlar kent formunda değişiklikler talep etmektedir. Değişimin boyutu, yönü ve hızı şehirlerin dönüşümünü talep edenlerin, yani şehir sakinlerinin, fiziksel ve ideolojik ihtiyaçlarına bağlı olarak farklılık göstermektedir. Değişim, aynı zamanda onu talep edenlerin değişimle birlikte gelen fırsatları değerlendirmeleriyle ve talepkârların finansal ve fiziksel kaynaklarıyla doğrudan alakalıdır (Colean, 1953, s.5). Değişimin başka önemli bir faktörü ise şehir sakinlerinin değişmesidir. Yapılan nüfus sayımlarına göre 1927'de 75.553 olan nüfusun (Aydın et al, 2005, s.530) büyük kısmını askerler ve memurlar ve sivil bürokratlar oluşturmaktadır (Nalbantoğlu, 2000, s.254).

Savaş sonrası hedeflenen büyüme daha iyi bir geleceği hayal ederek planlanır, çünkü böyle bir gelecek zaferin getirdiği bir ayrıcalık olarak görülmektedir. 1923 sonrası Cumhuriyet'in yeni başkenti Ankara'daki yeni yapılaşma, sosyal ortam ve fiziksel çevre de bu hayali yansıtmaktadır. Fakat 'yeni' olan, geçmişin bazı sembollerinden kopmayı da reddetmektedir, en azından 192328 arasında yeni başkent Ankara' da gerçekleşen durum budur.

Ankara'ya yeni gelenleri Ankara'nın sakinlerinin benimsemesi zaman almıştır. Ankara yerlileri, Kurtuluş Savaşı öncesinde yıllardır bozulmayan belli bir düzen içinde hayatlarını devam ettirmekteydiler. Kurtuluş Savaşı'na olan inançları ve destekleri, Ankara'nın başkent olmasıyla ödüllendirilmiş gibi olsa da, Ankara sakinleri, yeni gelenleri ‘yaban'lar olarak değerlendirmiş (Şenol-Cantek, 2011), Ankara'nın tarihi kent merkezindeki eski mahallelerinde gündelik hayatlarına devam etmişlerdir. Bu umursamazlık veya çekingenlik, Ankara yerlilerini Yenişehir'den uzak tutmuştur.

Şehrin kendi idari bünyesinin, yani belediye meclisinin gelişimi çeşitli gruplar arasındaki güç dağılımına bağlı olarak değişiklik gösterebilmektedir ve bu grupları Weber şu şekilde tanımlamaktadır (2000, s.221): Birinci grubu toprak ve/ya para sahipleri, kreditörler ve tüccar olan seçkinler, ikinci grubu şehirde örgütlenmiş loncalar, ve üçüncü grubu esnaf ve sanayi mallarının perakendecileri oluşturmaktadır. 1920'lerin Ankara'sının tanıklık etmiş olduğu meclisteki örgütlenme de buna benzerdir.

Ankara çevresinde bulunan, mübadele sonucu Ankara'yı terk etmiş olan Rum ve Ermenilere ait olan bağ evlerine Yenişehir'de inşaatlar devam ederken Ankara'ya gelen, devlet yönetiminde ve kuruluşlarında etkin olan kişiler 
ve aileleri yerleşmiştir (Cengizkan, 2002, p.119). Yani yerlilerin gözünde, Ankara'nın bağ evlerine de 'yaban'lar yerleşmiş, yerli Ankara sakinlerine sadece tarihi kent merkezi kalmıştır. Devlet yönetimi ise bir yandan Ankara'da yaşamak durumunda olan ve konut bulunamadığı için yüksek kiralar vermek zorunda kalan memurlara 1927 yılında devlet kira tazminatı ödemiş, böylece giderek kalabalıklaşan bürokratları ekonomik açıdan desteklemiş, bir yandan da mülk sahiplerine kaynak transferi sağlamıştır (Aktüre, 2000, s.59).

Tarihi kent merkezinde olduğu gibi Yenişehir de rant ile yüzleşmektedir. Ulus'tan Çankaya Köşkü'ne ulaşan bulvar üzerindeki arsalar, milletvekillerine ve devlet memurlarına ucuz fiyatlara satılmış, hatta arsaların değerinin zamanla artmasıyla birkaç kere el değiştirmiştir. Anadolu'nun ve İstanbul'un zenginlerinden milletvekili olup Ankara'ya gelenler Yenişehir'deki arsaları ve eski bağ evlerini yok pahasına almışlar ve sosyal tabakalaşmanın en üst kademeleri olarak Yenişehir'de kendilerine hâkimiyet kurmuşlardır (Aktüre, 2000, s. 60). Orta-üst sınıflar başlangıçta eski şehrin yeni evlerine ve apartmanlarına yerleşmiş, ancak Yenişehir'de inşaatlar bittikçe bu yeni yerleşim bölgesine taşınmışlar, aynı kullanıcı profilinden Hisarönü Mahallesi'ne yerleşmiş olanlar ise mahallenin ticari ve idari merkeze olan yakın konumundan dolayı bu mahallede oturmaya devam etmeyi tercih etmişlerdir.

Yeni başkent Ankara'da meydana gelen kent dokusunu bir yanda Yenişehir'in geniş arazisinde geniş avlular ve bahçeler içinde yer alan müstakil evler oluştururken, diğer yanda 1925 yılı öncesi acil konut talebinden dolayı eski kent merkezinde sıkışık alanlarda inşa edilen dar apartmanlar oluşturmaktadır. Hisarönü Mahallesi, eski kent merkezinde olmakla birlikte boş bir alanda 'yeniden' inşa edilen bir yerleşim yeri olarak, Ankara'nın iki ana yerleşim alanından da izler taşımaktadır, yani (küçük) avlular içinde müstakil evleri ve dar apartmanları aynı sokak üzerinde yanyana görmek mümkündür. Mahalle, bu karakteriyle de 1920'ler Ankara'sının yapısal karakterini temsil etmek ister gibidir.

\section{Günümüzde Mahallenin Dili - Terkedilmişlik, Yanlış Kullanım ve Yıkım}

Harvey (2006, s.35-36), mimari mekânların, kent sakinleri açısından 'anlamlar'ı olan mekânsal ilişkilere göre, yine aynı sakinler tarafından yeniden tanımlanmakta ve düzenlenmekte olduğundan bahsetmektedir. Yani bir bireyin veya topluluğun kendilerini çevreleyen mekâna karşı takındıkları tavır ve bu mekânı nasıl algıladıkları veya bu mekâna nasıl tepki verdikleri önem kazanmaktadır. Kent sakinlerinin kentsel uzama kabul ettirebilmiş oldukları (kentçiliğin kullanıcılara zorla kabul ettirdikleri karşısında) kendilerine özel 
'geri çekilme yerleri' vardır; yani kendi kullanımlarına ya da zevklerine göre özel mekânlar ve güzergahlar yaratmaktadırlar (Mayol, 2009, s.34). Mahalle kullanımları bu özel mekânların en sık görüldüğü yerlerdir. Kişilerin kendi hafizalarında mahalle 'silinmez bir aidiyetin işareti olarak' yer almaktadır (Mayol, 2009, s.36). Bu nedenlerden dolayı inşa edildiği zamana ve mekâna göre amaçlanan özgün kullanımı bakımından önemli bir dönüşüm geçirmiş bir mahallenin anlatımları dikkat çekicidir. Bu kısımda hala varlığını sürdürmekte olan 1920'lerin Ankara'sının Hisarönü Mahallesi'nde inşa edilmiş olan müstakil ev ve apartmanların tarihsel ve güncel biçimsel, yapısal ve mekânsal kullanımlarından bahsedilecektir.

Tarihsel anlatımında bakımsızlık ve süregelen bir terkedilmişlik sonucu kopukluk yaşamakta olan bu mahalle, günümüzde yıkımla yüzyüze geldiği bir dönemden geçmektedir. Mahallelinin ve kullanıcıların hafızasında bu uzun süreli terkedilmişlik sonucu geçmiş ile kopma gerçekleşmektedir. Fakat Nora (2006, s.19), hafızanın anımsama ve unutma diyalektiğine açık olduğundan, biçimlerin sürekli değişiminden habersiz olduğundan bahseder; bundan dolayı hafıza, uzun belirsizliklerden sonra ani dirilmelere elverişlidir. Çünkü iç içe geçmiş özel ve simgesel anılardan beslenmektedir; uzama, imgeye ve nesneye kök salmıştır. İncelenen yapılar, hem geçmişin izlerini taşıyarak mahallenin öyküsünü anlatmakta, hem de günümüzde o bölgede ihtiyaç duyulan işlevlerin tespitinde yol göstermektedir. Yani, konutların terkedilmişlik sonucu kaçınılmaz olan yıkımları yerine, yeniden işlevlendirilerek kullanım devamlılıkları sağlanıp, Nora'nın mekân hafızası üzerine belirttiği gibi, kullanıcının/mahallelinin zihninde ani dirilmelerle geçmiş ile bağ yeniden kurulabilir. Yani mahallenin ve yapılarının geçmişten anlatımları o dönemi anlamak için, güncel anlatımları da sürekliliği olan bir toplumsal hafızayı korumak ve gelecek nesillere aktarmak için önem kazanmaktadır.

\section{Konutlarn Tarihsel Anlatımı}

1920'ler Ankara'sinda üretilen konutlar hibrid veya eklektik bir karakter sergilemektedir. Bu karakter yapıların sadece biçimsel özellikleriyle, yani dönemin Birinci Ulusal Mimarlık Akımı'nın formal karakteriyle alakalı değildir. Yapıların sergiledikleri daha önemli bir özellik vardır. Yapıların cephelerinin gerisinde kayda değer bir yapısal, strüktürel ve mekânsal modernleşme süreci yaşanmaktadır.

Cephe karakterlerini incelediğimizde dönemin ideolojik yaklaşımlarının takip edildiği görülür. Yani Hisarönü Mahallesi'nde 1920'lerde inşa edilmiş 
yapılar biçimsel özellikleriyle Birinci Ulusal Mimarlık Akımı'nı takip etmektedir (Bozdoğan, 2012). Birinci Ulusal Mimarlık Akımı, Osmanlı İmparatorluğu'ndan yeni Cumhuriyet rejimine yeni geçmiş bir toplumun ulus-devlet inşası esnasında radikal bir geçiş yaşamaması için tercih edilmiş ve toplumun Müslüman, Selçuklu-Osmanlı kimlikleriyle birlikte Türkleştirilmesi yolunda izlenen politikaya cevap vermiştir. Batı ülkelerinde görülen eklektik - neoklasik dönemde de benzer kaygılarla kurulan ulus devletlerin kültürel kökenlerinin nerelerden geldiğini göstermek/anlatmak için bu mimari akımın cephe karakterlerinde geçmiş dönemlere atifta bulunulmuştur. Kemerli ve sivri kemerli profilleriyle pencereleri ve kapıları, geleneksel Anadolu evlerinin çıkmaları, çıkmaları taşıyan süsleme taş payandaları, kuleleri, çinili ve alçı-kabartmalı yüzey süslemeleriyle Osmanlı karakterini sergileyen bu konutların arka yüzlerini, yani esas 'batılılaşma' ve 'modernleşme' sürecini Cumhuriyet'in ilk on yılında bu cepheler saklamaktadır. Dönemin ulus-devlet inşası yanında modernleşme ve batılılaşma projesinin radikal bir geçiş yerine aşamalı olması, mimarlığın ideolojilerin uygulanması yolunda bir araç olarak kullanıldığını adeta kanıtlamak ister gibidir. Bu mahalle ve konutları ise toplumun geçirdiği bu değişim dönemini temsil ederek şehir sakinlerine önemli kanıtlar bırakmıştır.

Konutların sokak ile kurdukları ilişkinin anlattığı hikâye de önemlidir. Ankara'nın tarihi kent merkezi Ulus'un yangın sonrası boş kalan Hisarönü Mahallesi'nde yer alan yapı blokları incelendiğinde, birbirini kesen düz sokakları, net tanımlanmış adaları ve sokağa hizalanmış konutları, elbette ki Ankara'nın geleneksel konutlarının bulunduğu organik oluşumlu adalarından ve cul-de-sac patikalarından farklılık göstermektedir. Dahası, yapı adalarının formlarında radikal bir farklılık yaşanmıştır: Yapı adaları birbirlerinden koparılmış ve üçgen formunda önerilmiştir (Şekil 2). Bu uygulamada 19. yüzyıl Avrupa'sının şehir planlarından doğrudan etkilenmiş olan yabancı bir şehir plancısının etkisi büyüktür: Lörcher'in hem 1924 Ulus, eski şehir, hem de 1925 Yenişehir planları incelendiğinde üçgen formlu ada formasyonlarına sıklıkla rastlanmaktadır (Cengizkan, 2004, s. 59).

Konutlar, yine Ankara'nın geleneksel konut mahallelerinde olan düzenin aksine, mahalle içinde yükseklikleri ve boyutları bakımından homojen bir yapı izlemezler. Aynı sokak üzerinde iki katlı bir müstakil ev ve iki blok sonra beş katlı bir apartman birlikte gözlenmektedir (Şekil 3). Yine aynı dönemde, tarihi kent merkezinin en önemli akslarından biri olan Anafartalar Caddesi'ne yakın olan bu mahallede, ticari işlevlere de cevap verecek şekilde birçok konutun giriş katları ve giriş katları üstünde olan mezanin katları ticari 
mekânlar olarak kullanılmıştır (Şekil 3). Bu da mahallenin ve mahalle sakinlerinin gündelik yaşamı hakkında bize bilgiler vermektedir: Hisarönü Mahallesi, yeni bir mahalle olmakla birlikte Yenişehir'de bulunan konut bölgeleri gibi çevresinden yalıtılmış değildir ve ticari merkezin uzantısı mahalle içinde de devam etmektedir.

Yapıların birbirleriyle, sokakla ve avlularıyla kurdukları ilişkiler ise o dönemdeki eski şehrin merkezinde olan yerleşim bölgelerinin karakteri hakkında bilgi vermektedir. Bu bölge, yangın geçirmiş olmasından dolayı Yenişehir gibi boş bir arazi olarak kalmasına rağmen, Karaoğlan ve Anafartalar gibi ticari merkezlere yakınlığından dolayı fazla talep görmüş, ve döneminin eski şehrinde bulunan diğer yerleşim bölgeriyle morfolojik açıdan benzerlik göstermiştir. Yani, bu bölgenin apartmanları da küu̧ük parsellerde inşa edilerek 'dar' bir karakter sergilemiş ve köşe parsel örnekleri dışında çift taraflı kuşatılmaları için yan cepheleri kör ve sıvanmadan bırakılmıştır. Avlular ise sağlıklı bir yaşam ve sadece apartman sakinlerinin kullanabileceği yarı mahrem sosyalleşme mekânları sundukları için arzu edilseler de, Hisarönü Mahallesi'nde hızlı ve sıkışık yapılaşmadan dolayı çoğu yapı küçük bir iç/arka avlu ile planlanmıştır. Yani Ulus'un dış çeperine doğru olan mahallelerinde veya Yenişehir'in geniş arazilerinde olduğu gibi geniş avlulu evler veya apartmanlar Hisarönü Mahallesi'nde bulunmamaktadır.

Yapıların yapım teknikleri ve malzemeleri incelendiğinde ise yine bir toplumun modernleşme sürecinin farklı bir noktasına tanıklık edilmektedir. Yüzyıllardır geleneksel yapım teknikleriyle, yani taş ve özellikle kerpiç yığma ve ahşap iskelet sistemleriyle yapılmış olan Ankara konutları, 1920'lerle birlikte beton ve demir iskelet sistemleriyle tanışmıştır. Geleneksel konutların inşası yerine yeni yapım tekniklerinin benimsenmesinin nedenlerinden en önemlisi ise demografik, ekonomik ve gündelik hayatı değişen ve batılılaşan bir toplumun konut ihtiyacına sürekli yanan ve yeniden yapılmak zorunda kalınan ahşap konutların artık cevap vermiyor olmasıdır (Bertram, 2004, s.168). Büyük apartmanlar beton iskelet sistemlerine doğrudan sahip olsalar da küçük konutlar ve küçük apartmanlar karma bir yapım tekniğiyle, yani beton iskeletli veya yer döşemesi beton olan yığma yapım teknikleriyle inşa edilmişlerdir. Hisarönü Mahallesi konutlarında ise bahsedilen üç sistem de gözlenmektedir (DKVKE5 , 1996, 2010). Çoğu yapı ise karışık teknikle yapılmıştır ve günümüzde arazide yapılan gözlemle yapıların yan kesitlerinden ve bozulmuş cephe düzenlerinden yapım teknikleri rahatça anlaşılmaktadır.

\footnotetext{
${ }^{5}$ Doğal ve Kültürel Varlıkları Koruma Envanteri, Kültür Varlıkları ve Müzeler Genel Müdürlügü, Ankara Belediyesi.
} 
Hisarönü Mahallesi'nin 1920'lere ait olan konutları günümüzde terk edilmişliğin ve yıkım sürecinin yaşandığı güncel bir anlatımla yapım tekniklerini son kez şehir sakinlerine sunmaktadır.

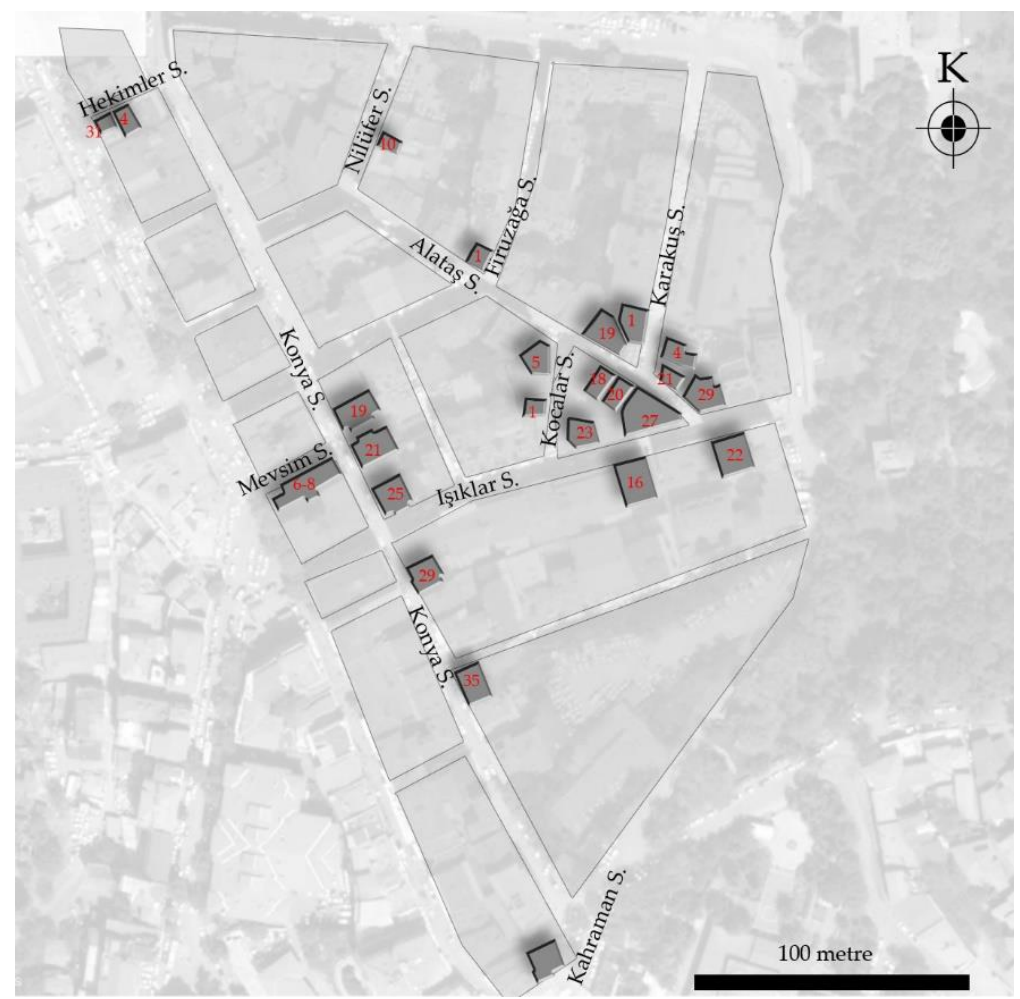

Şekil 2. Hisarönü Mahallesi ve 1920'lerde inşa edilmiş konutları. Konutların üzerinde binaların adres numaraları gösterilmektedir (Arka plan Kaynak: Google Maps, 2020). 


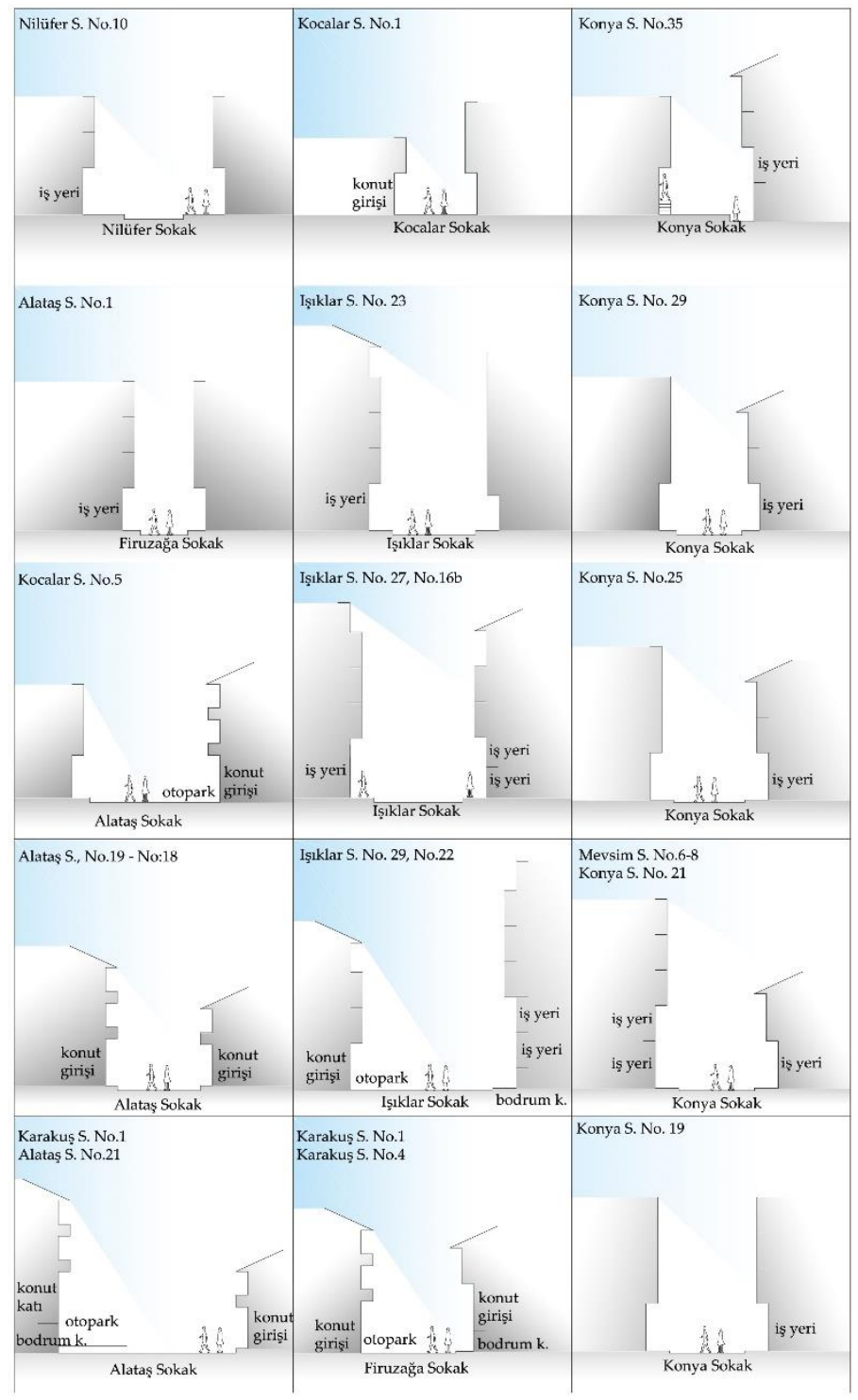

Şekil 3. Hisarönü Mahallesi'nden Sokak Kesitleri

Bu konutların gelenekselden moderne dönüşüm geçiren mekânsal karakterleri, 1920'lerde Cumhuriyet'in ilanı ve Ankara'nın başkent olarak modernleşme sürecine girmesiyle değişim geçiren ailelerin günlük hayatına ışık tutmaktadır. Konutların plan düzenlerine ve mekânsal ilişkilerine baktığımızda, geleneksel Osmanlı-Türk aile yapısının Cumhuriyet'in ilk on yılı gibi kısa bir sürede değişim geçirdiği görülmektedir. Geleneksel konutların kullanımında 
görülen geniş aile kurgusu aşamalı olarak çekirdek aileye göre dönüşmeye başlamış; yeni konutlar, Cumhuriyet'in modernleşme sürecinde kadınların iş ve şehir hayatına dâhil olmasıyla birlikte hayatı ev, iş ve okul arasında gelişecek olan anne, baba ve çocuklar için planlanmıştır. En önemli değişim ise tüm ailenin toplanma yeri ve ana dolaşım mekânı olarak tanımlanan sofa mekânının zamanla küçük ve merkezi hollere ve daha sonra koridorlara dönüşmüş olmasıdır (Şekil 4). Kimi geleneksel konutlarda sofa, sokakla ve avluyla ilişki kurabilirken, merkezi holler ve koridorların sokaklar ve avlularla ilişkileri kesilmiş; ortak kullanım mekânı olarak tüm odaların açılacağı bir toplanma mekânına gerek kalmamıştır. Dahası, sofayı çevreleyen benzer karakterli mekânlar, boyut, konum ve iç mekân süslemeleri gibi özellikleriyle birbirlerinden farklılaşmaya başlamıştır. Bunun nedeni sosyalleşmeye ve/veya mahremiyete önem veren tanımlı mekânların oluşmuş olmasıdır. 1920'lerle birlikte Ankara'nın en önemli dönüşümlerinden biri ise servis mekânlarının geleneksel konutlarda olduğu gibi avlularda değil, yaşama mekânlarının içinde olmasıdır. Servis mekânları, modernleşmenin sembolü olarak görülmüş ve banyosu olmayan ev hayal edilemez olmuştur (Aydın et al., 2005, s.435-436).

Şüphesiz tüm özellikleriyle her bir örnek bize farklı bir hikâye anlatmaktadır ve mahalle içinde merkezi sofalı plan düzenine sahip konutlarla sofaların koridorlara dönüştüğü plan düzenine sahip konutlar bir arada görülmektedir (Şekil 4). En sık rastlanan örnekler ise hem holün hem de koridorun bir arada kullanıldığı konutlardır. Bunlar, 1930'larda Uluslararası Üslup'la birlikte benimsenen koridor merkezli mekânsal kurguların ani değil, aşamalı olarak gerçekleştiğini ortaya koymaktadır (Şekil 4).
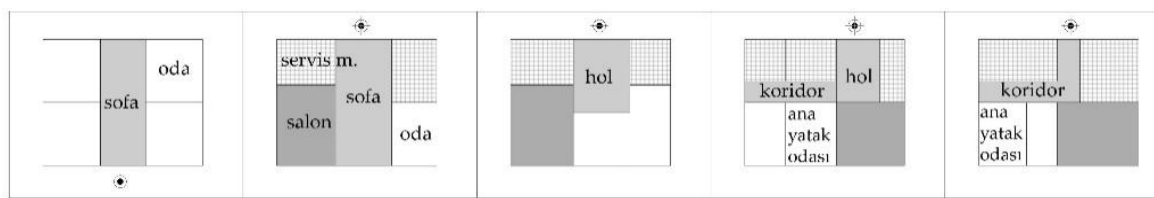

Şekil 4. Ankara' da 1920'lerde Üretilen Konutlarda Mekânsal Dönüşüm

\section{Konutlarn Güncel Anlatımları}

Üretim yeri olarak kullanılan konutlar: Bu konutların ortak özelliği günümüzde kullanımlarının devam etmesinden dolayı sahipleri veya kullanıcıları tarafından bilinçsiz olarak da olsa bakımlarının sağlanması ve yapısal olarak iyi durumda bulunmalarıdır. Özgün durumda sadece giriş katları ticari kullanıma ayrılmış olsa da günümüzde apartman daireleri veya müstakil evlerin üst katları da üretim yeri olarak kullanılmaktadır. Bu yapılar arasında 
Hatay Apartmanı olarak bilinen Hekimler No:4 adresli apartman (Aslanoğlu, 2010, s.267), Nilüfer (Çantacilar) Sokak No:10 adresli müstakil ev (Şekil 5a) ${ }^{6}$, Işıklar Sokak No:22 adresli 1920'ler Ankara'sının en yüksek apartmanı (Şekil 5b), Alataş Sokak No:1 adresli ve 1923-24 tarihli mahallenin ilk apartmanı (Şekil 5c), Konya Sokak No:19 adresli apartman (Şekil 5d) ve hemen karşısında bulunan Konya Sokak No:21 adresli müstakil ev (Şekil 5e) yer almaktadır. Kullanım devamlılığı sayesinde bakımları sağlanmış olan bu yapılar, maalesef yine aynı kullanımdan dolayı, özgün kullanım düzenlerinin tespit edilemeyeceği mekânsal dönüşümlere uğramışlardır. Bu dönüşümler, eski duvarların yıkılması, yeni duvarların örülmesi, servis mekânlarının kullanıma kapatılması ve oda olan mekânların servis mekânlarına dönüştürülmesi gibi tadilatlarla gerçekleşmiştir.

Bu mahallede süregelen sosyal pratikler çanta satım ve üretim yerleri (Nilüfer Sokak No: 10), deri üretim ve işleme yerleri (Alataş Sokak No:1 [kesme], Işıklar Sokak No:22 [yapıştırma], Konya Sokak No:19 [boyama]), elektrik malzemeleri satış dükkanları, basım evleri ve mahalle esnafına hizmet veren küçük lokantalar ve kıraathaneler (Konya Sokak No:19, No:21) şekilde sıralanabilir.

\footnotetext{
${ }^{6}$ Fotoğraflar Mimarhane Öğrenci Topluluğu Organizasyonu için Deniz Avcı Hosanlı tarafindan 16 Kasım 2019 tarihinde düzenlenen 'Ankara, Ulus - Tarihi Kent Merkezi Yürüyüşü' esnasinda topluluğa üye olan öğrenciler ve Avcı Hosanlı tarafindan çekilmiştir. Fotoğraflar: Deniz Avcı Hosanlı, H. Tuğba Yılmaz (Hacettepe Üniversitesi, İç mimarlık Bölümü, Yüksek Lisans öğrencisi) ve Yusuf Akkoyun (Ankara Yıldırım Beyazıt Üniversitesi, Mimarlık Bölümü, 3. sınıf öğrencisi).
} 


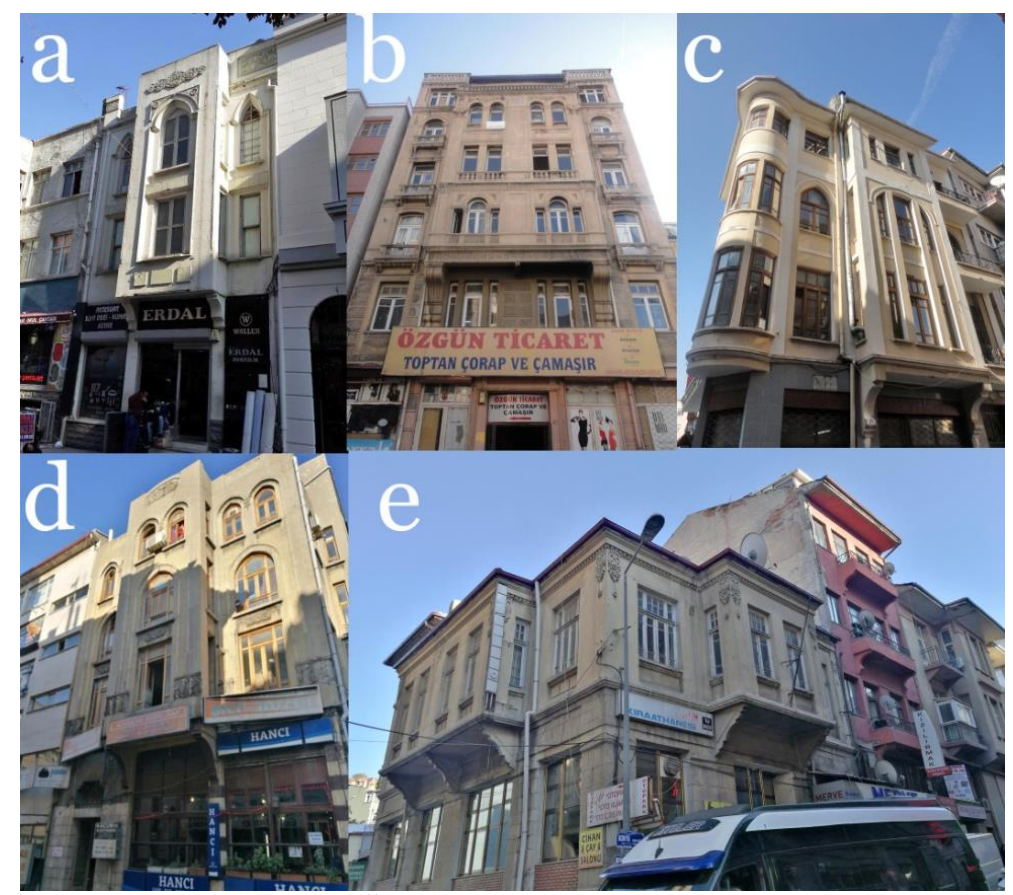

Şekil 5. Üretim için kullanılan örnekler

(D. Avcı Hosanlı arşivi, H. T. Yılmaz arşivi, Y. Akkoyun arşivi).

Depo olarak kullanılan konutlar: Kullanımları devam ediyor gibi gözüken bu konutların pencereleri beyaz kâğıtlarla örtülmüş ve kapılarına kilit vurulmuştur; yani terk edilme süreçleri başlamıştır. Bunlar arasında Işıklar Sokak No:29 adresli apartman (Şekil 6b), Kocalar Sokak No:5 adresli müstakil ev (Şekil 6a), Konya Sokak No:29, 25 ve 35 adresli apartmanlar (Şekil 6c, 6d, 6e) bulunmaktadır. Daha önce 2018 yılında bunların arasında Alataş Sokak No:20 (Şekil 7a) adresli ve Karakuş Sokak No:4 (Şekil 7c) adresli müstakil evler de sayılabiliyor olsa da, 2019 yılı itibariyle bu yapılar da terk edilmişlerdir ve doğal süreçte dayanımlarını kaybetmeleri sonucu yıkılmaları beklenmektedir. 


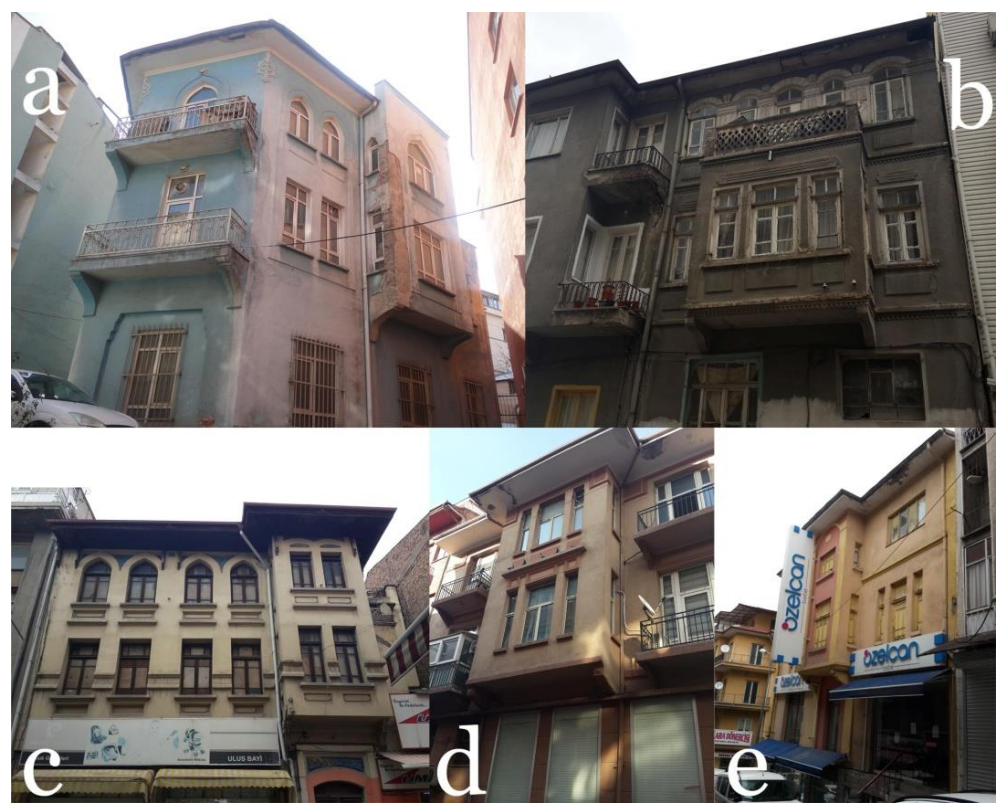

Şekil 6. Depo olarak kullanılan örnekler

(D. Avcı Hosanlı arşivi, H. T. Yılmaz arşivi, Y. Akkoyun arşivi).

Terk edilmiş ve yıkılmaya yüz tutmuş konutlar: $\mathrm{Bu}$ yapılar ise bir önceki süreçten geçtikten sonra, doğal yollarla gelecek sonlarına karşı sabırla direnmeye devam etmektedir. Artık kullanılmayan fakat Hisarönü Mahallesi'nden 1920'lere ait kesitleri son defa sunan bu örnekler arasında bir önceki kısımda bahsedilen Alataş Sokak No:20, Karakuş Sokak No:4 adresli müstakil evler, Kocalar Sokak No:1 adresli başka bir müstakil ev (Şekil 7b) ve Alataş Sokak No:20 adresli müstakil ev (ki ikizi kullanımdadır) (Şekil 8b) bulunmaktadır. Mahallenin en çarpıcı örneği yine maalesef bu kategoridedir; üçgen bir bloğun köşesine yerleştirilmiş olan Işıklar Sokak - Alataş Sokak kesişiminde kalan (Işıklar Sokak No:27) Erzurumlu Nafiz Bey Apartmanı yıllardır yıkıma karşı direnmektedir (Şekil 7d). Üstelik apartmanın mimarının ise müteahhit Nafiz Kotan'la iyi iş ve arkadaşlık ilişkileri olan Arif Hikmet Koyunoğlu olduğu düşünülmektedir (Kuruyazıcı, 2008, s.45-46). Tüm bu özellikler bakımsız cephesini, kırılmış pencerelerini, kepenkleri indirilmiş dükkânlarını korumaya yetmemiştir. Bir başka örnek ise Mevsim Sokak No:6-8 adresli, Ankara'nın ilk sıra apartmanı olan yapıdır. Her bloğu farklı bir fiziksel değişim içindedir ve Konya Sokak cephesi olan blok terk edilmiştir (Şekil 8d). 


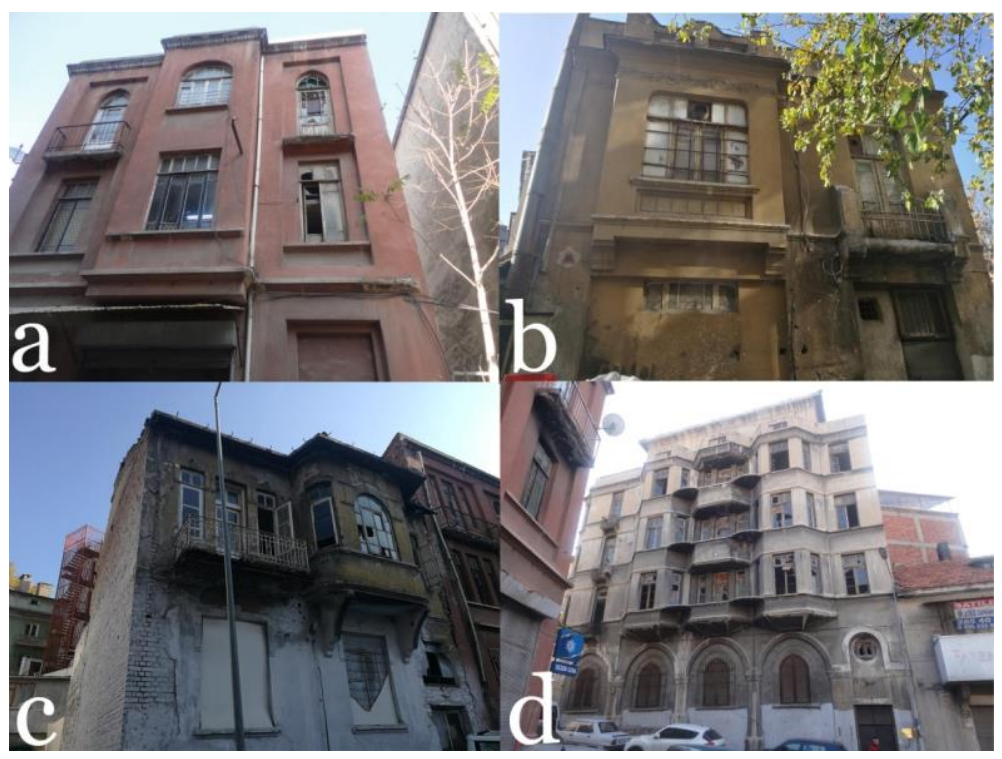

Şekil 7. Terk edilmiş örnekler

(D. Avcı Hosanlı arşivi, H. T. Yılmaz arşivi, Y. Akkoyun arşivi).

Bakımı düzenli yapılmakta olan konutlar: Bu yapıların diğerlerine göre daha şanslı olduğu kabul edilse bile, ki aralarında günümüzde kullanımı saptanamamış Işıklar Sokak No:16b adresli apartman (Şekil 8a) ve Alataş Sokak No:18 adresli Kızılay Kurumu şubesi olarak kullanılan müstakil ev (Şekil 8b) bulunmaktadır, ciddi dönüşüm geçirmiş örnekler vardır. Örneğin, Işıklar Sokak No:23 adresli apartmanın uğradığı dönüşümden dolayı (Şekil 8c) apartman arazi çalışmaları sırasında tespit edilememiş, 1928 tarihli bir kartpostalla yapım dönemi belirlenebilmiştir (Şekil 9). Ankara'nın ilk sıra apartmanı olarak tanımladığımız Mevsim Sokak No:6-8 adresli apartmanın Anafartalar Caddesi'ne cephe veren sırası ve yanındaki diğer iki sıranın ise bakımı yeni yapılmıştır (2019) (Şekil 8d). 


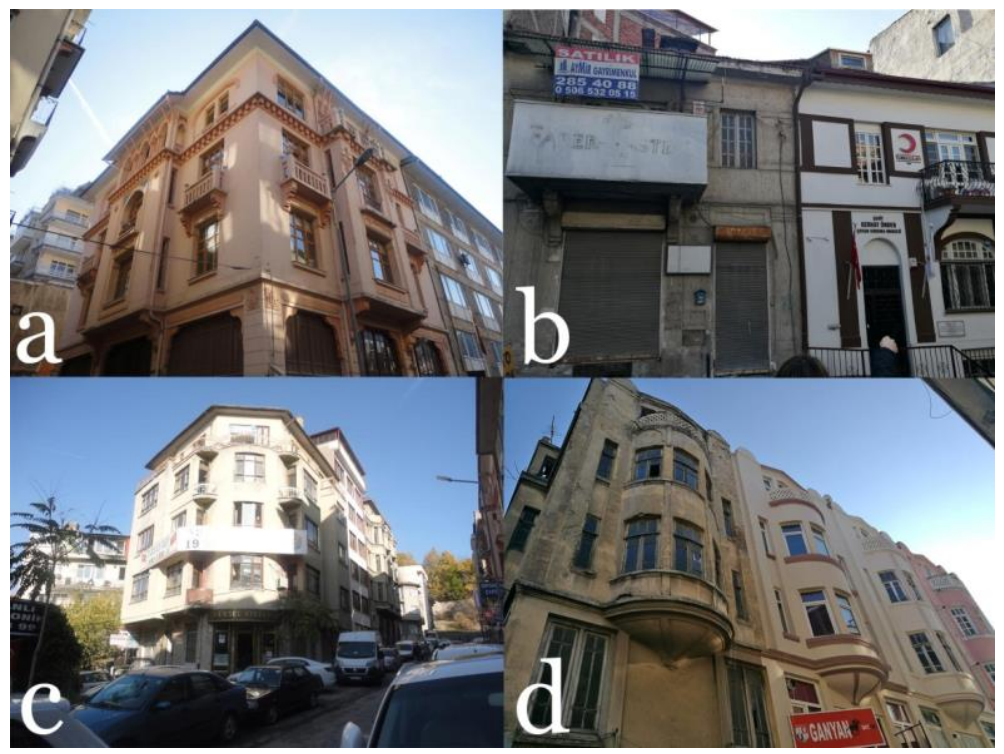

Şekil 8. Bakımı yapılmakta olan örnekler

(Avcı Hosanlı arşivi, H. Tuğba Yılmaz arşivi, Yusuf Akkoyun arşivi).

Yikılmış ama kartpostal ve fotoğraflar aracılığıyla anlatım yapan konutlar: Bu konutlar ancak kartpostallar ve fotoğraflarla tespit edilmekte ve mahallenin fiziksel olarak varlığını devam ettiren konutlarıyla olan ilişkileri ve benzerlikleri bu yolla analiz edilmektedir. Mahallenin 1920'lere ait olan karakteri ve ruhu bu belgeler üzerinden okunabilir olsa da (Şekil 10), bu yapıların ne tür nedenlerden dolayı yıkıldığ bilinmemektedir.

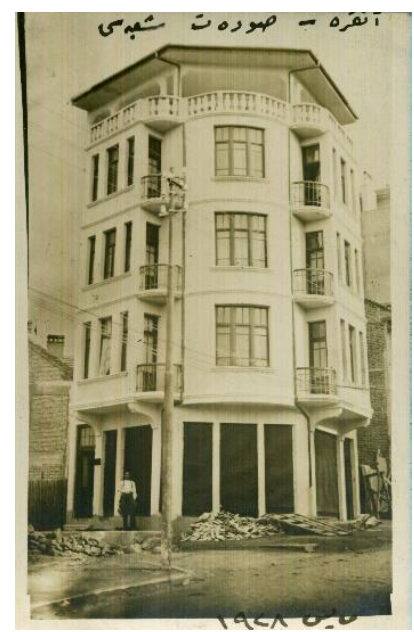

Şekil 9. Işıklar Sokak, No: 23 adresli apartman (İ.B.B. Atatürk Kitaplığı, 1928). 


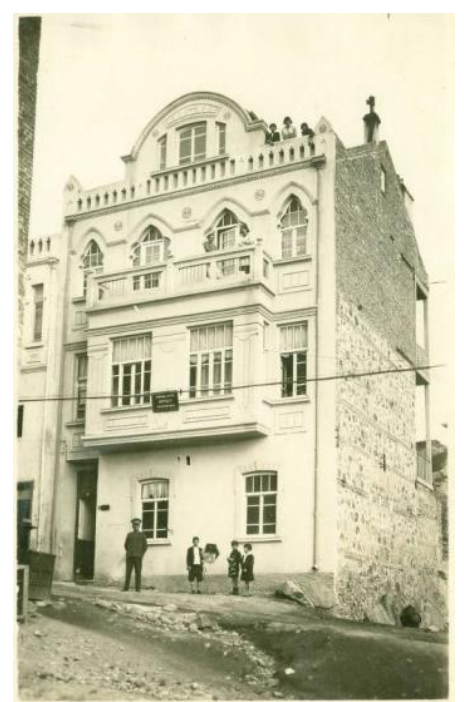

Şekil 10. Konya Sokak üzerinde yıkılmış bir apartman (VEKAM, t.y.)

\section{Mahallenin Anlatımını Devam Ettirmek: Bilinçli Kullanım ve Süreklilik}

Halbwachs (2017, s.142), 'mekân grubun izini taşır ve grup da onunkini' demektedir; sokaklar ve binalar aynı kaldığı sürece kent değiştiğini hissetmemektedir. Kentin genel fiziksel görünüşüne normalde ilgi göstermeyen topluluklar, herhangi bir sokağın, binanın ve evin yok olmasına karşı hassasiyet göstermektedir (Halbwachs, 2017, s.142-43). Çünkü topluluklar veya şahıslar aksilikler karşısında sarsıntı geçirdikleri zaman, fiziksel çevrenin varlığının herhangi bir etki altında kalmadan devam etmesi onlara güven vermektedir. Tarihi yapılar veya bölgeler ortak geçmişin bir ikonu haline gelmekte ve uyandırdıkları duygular ortak bir geçmişe ve kimliğe ait olmayı hissettirerek, insan ve tarihi bölge ve/ya yapılar arasında duygusal bağlar oluşturmaktadır (Bertram, 2004, s.183). İnsanların hafızasında o yapılar artık değerlidir çünkü geçmişlerinin anılarına bu yapılarla ulaşabilmekte ve sahip çıkabilmektedirler. Halbwachs (2017, s.145-46) bu ilişkiyi şu şekilde açıklamaktadır:

Evler, sokaklar ve buralarda oturanların oluşturdukları gruplar arasında yalnızca rastlantısal ve kısa süreli bir ilişki bulunsaydı, insanlar evlerini, mahalleleri, şehirlerini yıkıp... yenilerini yapabilirdi; oysa taşlar oradan oraya taşınabiliyorsa da, taşlar ve insanlar arasında kurulmuş ilişkileri değiştirmek o kadar kolay değildir... Taşlar ve malzemeler size direnmez. Oysa gruplar direnecektir...

Eski yerleşim bölgeleri ve ticari bölgeler bozulmanın ve çürümenin karmaşık ağında takılı kalmışlardır; uzun zaman iyi bir şekilde hizmet vermiş 
olan birçok kamu ve konut yapısının bakımları ekonomik açıdan yük görülmüş ve bu yapılar güncel ihtiyaçlara cevap vermediği için terk edilmişlerdir (Van Huyck ve Hornung, 1963, s.11). İçinde yıpranmış ve/ya terk edilmiş bölgeleri olmayan bir şehir, dinamik bir şehir olarak kabul edilemez ki zaten şehirler, arkeolojik kalıntı haline dönmedikleri ve içinde insanlar yaşamaya devam ettiği sürece sürekli değişim ve dönüşüm içindedir (Colean, 1953, s.5-6).

Kentler içinde eski olarak tanımlanan bölgelerin belirgin avantajları bulunmaktadır. Bunlardan biri şehirlerin tarihsel değeri olan yerleşim bölgelerinin etraflarında gelişmeleri sonucu bu tarihsel bölgelerin şehirlerin ticari merkezlerinde kalmalarıdır. Fakat, hızla büyüyen ve gelişen şehirlerin hızına yetişemediklerinden, hemen hemen tüm çağdaş şehirlerde merkezde kalmış olan tarihi kent dokusunda bozulmalar görülmektedir. Bunun nedeni bu yapıların ekonomik fayda sınırlarının altında kalmış olmaları veya güncel işlevlere cevap veremiyor olmalarıdır (Colean, 1953, s.3). Bu bozulma/çürüme sürecine çağların değişen şartlarına yetişemeyen müstakil ev ve apartmanlarda daha sık rastlanmaktadır.

Mahalle, blok, yapı gibi tarihsel fiziksel çevrenin deneyimlenebildiği zamanlarda şehir sakinlerinin tarihle kurduğu bağ güçlenmektedir. Bu bağ, geçmişin günümüze ve geleceğe taşınmasında ve dolayısıyla tarihsel bölgenin yadigârlık değerinin korunmasındaki en önemli etkendir (Dobby, 1978, s.16). İnsanlar manevi değerleri olan geçmişe ait mekânlara özlem duymaktadır ve bu karakterin yok olması yerine sürekliliğini talep etmektedir. Bu tür bölgelerde sürekliliği sağlamak ise kentsel koruma projeleri ile mümkün olmaktadır. Belediye servislerinin çabaları, çürümeye/bozulmaya yüz tutmuş bölgelerde yetersiz kalmaktadır ve iyileştirilmek yerine unutulan bu yapılar çağlar geçtikçe eskimeye devam etmekte ve bakılması gereken yapıların sayısı artmaktadır. Eski binalar yıkılmadığı gibi birikmekte ve içlerinde bulundukları mahalleler de eski canlılığına asla kavuşamamaktadır, çünkü çürüme/yokolma bulaşıcı bir hastalık gibi yayılmaktadır ve yayıldıkça fiziksel ve kullanım bakımından iyi durumda olan mahallelere de sıçrayacaktır (Van Huyck ve Hornung, 1963, s.14). Bu durum, çevredeki ticaret faaliyetlerinin azalmasına yol açacak, iş yerlerinin terk edilmesiyle ve sonuç olarak konutların, dolayısıyla mahallelerin değerlerinin düşmesiyle sonuçlanacaktır. Bunu engellemek için bilinçli bir iyileştirmeye, yani bir koruma planlamasına ihtiyaç doğmaktadır.

Halbwachs'a göre (2017, s.79-85), bir toplumun yapısını sarsan, kısmen y1kan, yenileyen bir olayın ertesinde yeni bir dönem başlamış olur. Tarih açı- 
sindan olaylar zincirleme olarak devam ettiği için, dönüşümler de birbirinden bağımsız değildir ve tarihin diğer kısımlarına etki etmektedir, dolayısıyla zaman zaman yeni bir değişime ihtiyaç vardır. Şehirlerin sonsuz dinamiği içinde değişim kaçınılmaz olsa da, şehrin her bölgesinde değişim oranı aynı değildir. Her kuşak bir önceki kuşaktan miras aldığ 1 şehirde hala kendisine faydalı olan kısımları, bölgeleri kullanmaya devam eder, çağdaş ihtiyaçlarına göre günceller, gündelik ihtiyaçlarına göre fayda sağlayamadığı bölgeleri ise ya terk eder, ya yıkar ya da ihtiyaçlarına yönelik yeniden işlevlendirir veya kentsel dönüşüm süreci başlar. Aralarında en mantıklı olan yeniden işlevlendirme aracılığıyla koruma seçeneği maalesef genellikle masraflı bir yöntem olarak görülmekte ve tercih edilmemektedir. Oysa yeniden işlevlendirme y1kıp yeniden yapmak demek değildir, tam tersine o bölgenin bozulmaya yüz tutmasına yol açan eksiklikleri tespit etmek ve bu eksiklikleri gidermektir.

Koruma yaklaşımı belirli ikilemlerle karşılaşmaktadır; bunlar sosyo-ekonomik kaygilar, centrifikasyon (gentrification: şehir-güzelleştirme, soylulaştırma) ve geçmişe yönelik koruma yaklaşımları arasında kalmaktan doğmaktadır (Dobby, 1978, s.18). Örneğin, Hisarönü Mahallesi'ni koruma yaklaş1mında sosyo-ekonomik öncelik gözetilerek yapıların iş yeri veya üretim yeri olarak sürdürmekte oldukları yaşamlarını ve işlevlerini devam ettiren bir koruma projesi geliştirilebilir. Bu koruma projelerinde, mahallede sürdürülmekte olan sosyal pratikler tespit edilip devamlılıkları sağlanabilir; örneğin, çanta ve dolayısıyla deri işleme (boyama, baskı, dikme) tesislerine çalışmanın konusu olan konutlarda sık sık rastlanmıştır. Terk edilmiş ve doğal yıkım süreci başlamış olan konutlar da aynı şekilde işlevlendirilerek, zaten mahallenin günümüzdeki karakterini oluşturan zanaatkârlara ve esnaflara kiralanabilir.

Başka bir yol ise mahalleyi eski canlılı̆̆na kavuşturmak için yapıları özgün işlevlerine geri döndürmek ve tarihindeki özgün kullanımı canlandırmak olabilir (Bu yaklaşım, o zaman tarihsel sürecindeki yakın dönem nasıl korunacaktır sorusunu da beraberinde getirir). Başka bir seçenek ise centrifikasyon olarak kabul edilir ki bu da mahallede görsel ve kültürel bir yenilemeye gidilerek mahallenin özgün halinde bulunan ve yıllardır yaşamakta olduğu tarihini silmek, bellek değerini kaybetmesine ve yapıların ruhsuz kabuklara indirgenmesine yol açmak demektir. Burada öncelikli olan tarihi yapının uğrayacağı müdahalelerden ötürü yaşayacağı değişimi minimuma indirmektir. Müdahaleler arasında bulunan tamir etme (repair) ve koruma (preservation, conservation) kavramları en az değişim gerektiren işlemler olarak kabul edilirken, iyileştirme (enhancement), restore etme (restoration), yeniden 
inşa-etme (re-construction) ve yıkım (demolition) az, çok veya bütüncül bir değişimi beraberinde getirmektedir (Dobby, 1978, s.19).

Şehirlerin dinamik kalabilmesi için de, yenileme, süreklilik gerektiren bir süreç olarak planlanmalıdır. Halbwachs (2017, s.145) şehirlerin tarihin seyrinde dönüşüm geçirdiğinden, eski evlerin yavaş yavaş harap olduğundan, ve önceden zenginlerin oturduğu sokakların, az gelirli nüfusun akınına uğradığından ve dolayısıyla çehre değiştirdiğinden bahsetmektedir. Fakat hızlı da olsa, aşamalı olarak gerçekleşen yavaş bir süreç de olsa, değişim her zaman kısmidir. Bir mahallede yıkıma gidilmemişse ve o mahalleye ciddi müdahaleler yapılmamışsa veya eski binalar yenileriyle değiştirilmediyse, mahalle bir anlatım yapmaktadır. Tarihsel ve görsel olarak, en önemlisi de bellek açısından, o mahalle şehrin insanları için değerlidir. Dahası, mahallelerin merkezi konumlarından ve yapılarının tarihi karakterlerinden dolayı yeniden işlevlendirme projelerinin sakinlerine sağlayacağ fayda, yıkımların oluşturacağı travmayı şüphesiz engelleyecektir. Üstelik son yıllarda, korunması gereken tarihi mahallede yaşamakta olan veya o bölgeye ilgi duyan gruplar; yani, uzmanlar, politikacılar, etnik veya dini kökenli gruplar veya özellikle mahalle toplulukları, ekonomik kalkınma, mekânın ruhunu hissetme ve ekonomik kalkınma sonucu sosyal güvence kazanma gibi sosyal yararlar sayesinde koruma sürecine dâhil olmak istemektedirler (De la Torre, 2005, s.4).

Günümüzün yıkıcı yaklaşımlarının arasında eski mahalleler, kentsel büyüme ve gelişmenin arka planında kendi hallerine bırakılarak bir leke gibi kalmalarına rağmen direnmeye devam etmektedir. Peki bu terk edilmişlik veya kendi haline bırakılmışlık sonucu, o tarihi bölge, daha ne kadar kendini anlatmaya, tarihsel ve belleksel değerini koruyarak, zamana karşı koymaya devam edebilecektir? Belediyeler tarafından sunulan çözümler, yani sürekli büyüme ve genişleme, eski bölgelerin devamlılığının garantisini vermemektedir ve bu durum Ankara'da sürekli ön plana çıkmaktadır. Doğal süreçte y1kılmaları beklenen (hatta arzu edilen!) yapıların yerine ise araç park yerleri (otopark) yapılmaktadır.

Kimi şehirlerde eski şehri ve yeni şehri tanımlamak kolay gözükmektedir. 1923 sonrası başkent olan Ankara'da bu tanımlama sadece eski şehir, yani tarihi kent merkezi olarak kabul edilen Ulus bölgesi, ve tamamen yeni yerleşim bölgesi olarak sıfırdan inşa edilmiş olan Yeni Şehir olarak bilinen bölge tanımlarında söz konusu olmakta gibi görülmektedir. Oysa Ulus'un içinde eski olanla yeni olanı, yani Cumhuriyet öncesi ve sonrası zamanı ve yapılarını net bir şekilde ayırabildiğimiz sınırlar çizmek güçtür. Eski mahalleler yeni yüksek yapılarla çevrelenir ve eski yaşam görüntüsünü sürdürmeye devam 
eder. Oysa yenilerin yanında bakımsız kalmış ve terk edilmeye yüz tutan eski yapılar yıpranmışlık sergiler ve sakinleri zaman içinde o bölgelerde barınmayı tercih etmeyeceği gibi, bu yapılarla ilgilenmekten de vazgeçebilirler.

Ankara'nın başkent olmasıyla Ulus'un hemen hemen her bölgesinde eskinin yanında yeninin inşaatı başlamıştır. 1916 Yangını sonucunda tamamen yanmış olan Hisarönü Mahallesi eskinin içinde yeni olan bir karakter sergilemiştir. Fakat 1920'lerde edindiği bu karakter, günümüzde aynı yapıların eski kalarak yanlarına sonraki dönemlere ait nitelikli/niteliksiz yapıların inşa edilmesiyle eski ve yeninin yan yana olduğu bir karaktere dönüşmüştür.

Mahallenin ve konutlarının problemleri ise tüm diğer şehir merkezinde kalmış tarihi mahallelerin problemleriyle benzerlik göstermektedir; yani bina parselleri küçük, kent doku oluşumu plansız, sokaklar dar ve tesisat yetersizdir (Van Huyck ve Hornung, 1963, s.13). Oysa kaderine terk edilmiş Hisarönü Mahallesi'nin erken Cumhuriyet konutlarında bu eksiklikleri gidermek veya iyileştirmek için gerekli altyapı bulunmaktadır.

Koruma projelerinde devletin, yerel yönetimlerin, kamu kuruluşlarının ve özel işbirlikçilerinin ve yatırımcılarının destekleri gerekmektedir. Devletin kamulaştırma yetkisi bulunmaktadır, yani tarihi alan ve/veya mahalle, daha sonra sahiplerine geri teslim edilmek üzere devlet tarafından geçici bir süreliğine koruma amaçlı satın alınabilir. Bu sayede devlet, profesyonellerin yardımıyla ortak kullanım alanlarında iyileştirme girişimlerinde bulunabilir: Sokakları ve kaldırımları yeniler, araç park yerlerini belirler, mahallenin alt yapı ve tesisat bakımını yapar, park alanları tanımlar ve gerekiyorsa okullar gibi yeni kamusal hizmet binaları önerir ve inşa eder (Van Huyck ve Hornung, 1963, s.16). Devlet eliyle yapılan bu tür yatırımların özel girişimcilere katkısı büyüktür. Terk edilmeye yüz tutmuş yapıların sahipleri ve kullanıcıları, bakımlı bir mahalle içinde bakımlı yapılar isteyecekler ve bu yönde girişimlerde bulunacaklardır. Aynı şekilde yapılar satılacak olsa dahi özel girişimciler bu yapılara yatırım amaçlı sahip olmak isteyeceklerdir, çünkü bu alanlar ticari ve kültürel olarak zenginleşmeyi de beraberinde getirecektir.

\section{Sonuç}

Modern kentlerde yıkımlara rağmen eski kentin tarihsel özellikleri ve ruhu, eski mahallelerde yeni yapıların arasında kalmış eski yapılar ile hala hissedilmektedir. Fakat, günümüzde kentlerde eskinin kullanımının devamı yerine yık ve yap yöntemi izlenmekte ve tarihi kentlerimiz yok olmaktadır. Ankara'nın tarihi kent merkezinde yık ve yap yönteminin hain sonuçları her geçen 
gün artmakta, tarihi yapılar yıkılıp araç park (otopark) alanlarına dönüştürülmekte veya bilinçsizce yapılan restorasyon projeleri geçmişin izlerini ortadan kaldırmaktadır.

Eski kenti ve gündelik hayatını hayal etmek, var olan yapılar ve izlerle daha kolaydır, çünkü bu kalıntılar ve izler bize geçmişin gündelik hayatının bilgilerini sunmaktadır. İzlerin varlığı, der Halbwachs (2017, s.131), eski topluluğa özgü zamanın kalıcılı̆̆ını ve sürekliliğini açıklamaya yardımcı olur ve toplumlar değişim ve dönüşüm geçirse de geçmiş ve gelecek yan yana varl1ğını sürdürmeye devam eder. Bu çalışmada, geçmişini ve geleceğini yanyana sürdürmeye devam eden, Ankara'nın tarihi kent merkezinde yer alan, 1920'ler gibi önemli bir kırılma dönemine ait olan bir mahalle incelenmiştir. Bu mahalle, erken Cumhuriyet döneminde 1916 yangını sonucu başka bir hafızanın yitmesiyle boş kalan bir arazide yeniden, yeni bir hafıza oluşumuyla inşa edilmiştir.

Bu çalışmada kentin dili farklı bir yaklaşımla ele alınmış; mahalle ve konutlarının insan ile analojisi yapılarak geçmişe ve günümüze dair anlattıkları üzerinden değerlendirme yapılmıştır. Söz konusu mahallenin ve konutlarının, geçmiş ve güncel yaşamları hakkında anlattıkları belgelenmiş, tarihsel önemleri tartışılarak hafıza değerlerinin üzerinde durulmuş ve güncel sürdürülmekte olan hafızanın tehlikede olduğuna dikkat çekilmek istenmiştir.

Terkedilmişlik sonucu yıkımların bekleyen 1920'ler Ankara'sının konutları, üslupsal olarak tarihçi yaklaşımlı cephelerinin arkasına saklanmış modern teknikleri, donanımları ve mekânsal dönüşümleriyle hibrid karakter sergileyerek dönemin gündelik hayatından inşaat sektöründeki gelişmelere, değişen aile yapısından konut içi kullanımlardaki dönüşümlere kadar geniş yelpazede bilgi aktarmaktadır. 1920'lerden kalan ve yapısal bütünlüğünü tamamen kaybetmemiş tek ve son mahalle olarak günümüzde varlığını devam ettiren Hisarönü Mahallesi, döneminin ruhunu ve barındırmakta olduğu hafızayı gelecek nesillere taşıması için açık hava müzesi olarak korunmayı hak etmektedir. 


\title{
Extended Abstract
}

\section{Narrative of a Neighborhood and its Housing from the 1920s' Ankara}

\author{
* \\ Deniz Avc1 Hosanl1 \\ ORCID: 0000-0003-1157-5654
}

In studies regarding 'discourse', 'language' becomes the key notion. 'Discourse' can be defined as the production of verbal and written words as well as the long-term reproduction of all of them by social groups (Rey, 1995, p. 168; Basa, 2000, p. 19). Over the long term, 'language' is not the only norm that is constantly reproduced. The narratives by the human-made objects (buildings, architecture, and city) give clues about a specific time and place, and can be enriched with 'reproductions' by individuals and social groups. This 'reproduction' does not change the memory and/or spirit of that place; on the contrary, it provides continuity to it.

Cities contain all kinds of signs and symbols, and the people attribute certain meanings to them (Harvey, 2006, p.35-37). The bond (positive reaction, attitude) established between the neighborhoods and their inhabitants form the 'spirit' of 'place' and that 'place' occupies the memories of people and communities. As the centuries progress, the loss of the original memory is expected as historic neighborhoods and buildings face constant refunctioning by their users. However, when abandoned, the bond established between the neighborhoods and their inhabitants are entirely lost.

The neighborhood examined in this study, the only remaining one from the 1920s' Ankara with its spatial, formal, and structural integrity, is currently in this unfortunate process. Hisarönü Neighborhood is a neighborhood of 'reconstruction' after Ankara became the new capital of the Turkish Republic in 1923. It was reconstructed on a site of desolation by a devastating fire in 1916 which burned almost an entire section of the old city occupied by the minority groups. Its reconstruction was an attempt of creating a new memory space on a lost memory space from the pre-Republican Ankara (Figure 1). 
This study aims to understand the narrative of the Hisarönü Neighborhood on its historic and recent past and its current issues, consequently to discuss conservation approaches which would prevent the neighborhood's inevitable fate. In these discussions, the city, the neighborhood, and its housing are approached as organisms, i.e. the language of the historical region and its structures are analyzed by making an analogy between people, cities, and buildings (Colean, 1953, p.9).

In August 1916, a fire broke out in the Hisarönü Neighborhood in Ankara that burned three-quarters of the historic city, especially the rich neighborhoods of Ankara inhabited by the minorities. After the establishment of the Republic, due to housing crisis because of the increasing population, the desolation at the historic city center with its proximity to the main commercial and administrative center of the city was considered as an opportunity for a new settlement area and consequently was preferred by the middle and middle-upper classes.

In people's memories, their neighborhoods are 'indelible signs of belonging' (Mayol, 2009, p.36) and neighborhoods convey a narrative of a certain time and place. This study looks at the narrative of the Hisarönü Neighborhood via its formal, structural, functional and spatial characteristics of its housing from the 1920s' Ankara. The examined buildings tell the story of the historic neighborhood by bearing the traces of the past while with their current narratives determine the current usage that provides clues of the required refunctioning to keep them in constant use.

\section{Historic Narrative.}

The housing constructed in Ankara during the 1920s display a hybrid/eclectic character. This character was not simply related to the formal appearances, namely the eclectic character of the First National Architecture Movement of the period. This modernization process started from the planning of the neighborhood: Hisarönü Neighborhood was planned with straight streets intersecting each other, consequently forming clearly defined building blocks with street-aligned houses (Figure 2). Moreover, unlike the traditional residential neighborhoods, Hisarönü Neighborhood was not homogeneous in terms of the height and size of the buildings and most had ground floors reserved for commercial uses due to the proximity of the neighborhood to the main commercial street (Figure 3).

The construction industry also started to undergo changes when the traditional construction techniques (stone, mudbrick masonry and timber frame 
structural systems) were replaced with new materials and new structural systems of concrete and iron. Perhaps the most significant change occurred in the spatial characteristics of the housing units in line with the modernization agenda. With the change in the family structure (grand family to small family), the inclusion of the service spaces to the interiors, and the change in the perception of the privacy-publicity notions, the plan layout and the usage scheme started to show variations and the individual circulation spaces and rooms started to show characteristics according to predefined functions (Figure 4).

\section{Current Narrative.}

${ }^{*}$ Housing used as industrial production sites: The common feature of these buildings is that they continue to be maintained, albeit unconsciously, by their owners or users, and they are structurally stable. In these, as in their intended usage, the ground floors are reserved for commercial uses, however, the upper floors, unlike their intended usage, are used as mercantile production areas (Figure 5).

${ }^{*}$ Housing used as storages: Although these buildings are still in use, they are neglected and under constant lockdown, structurally stable but dilapidated (Figure 6).

*Abandoned housing facing demolition: These buildings are abandoned and continue to resist the inevitable demolition (Figure 7).

${ }^{*}$ Housing in regular maintenance: These buildings are still in use however have undergone serious transformation (Figure 8, 9).

*Demolished housing narrating via photographs or postcards: Via these, the demolished examples are morphologically connected to their surviving contemporaries. Even though these documents contribute to the spirit of the neighborhood (Figure 10), the reasons for their demolishment remain unknown.

\section{Continuation in the Narration of the Neighborhood: Conscious Use and}

\section{Perpetuity.}

Historical buildings or regions can become icons of the common past, and emotional bonds between people and historical sites and/or structures evoke the feeling of belonging to a common past and identity (Bertram, 2004, p.183). When there is continuity in the usage of the historical environment with its buildings, practices etc., the bond between the inhabitants of the city and its history is strengthened. 
This can be established with a conservation project which aims to preserve their original and/or current functions. For the latter, in the Hisarönü Neighborhood, most of the analyzed housing examples from the 1920s are currently used as mercantile production facilities where the produced goods are also distributed to the craftsmen working in the area (especially leather production). Thus, they can be conserved with an adaptive reuse project focusing to preserve current functions and rented to craftsmen and tradesmen who already form the current guilds of the neighborhood.

The problems of the historic neighborhoods are common: the small building lots, unplanned urban development, lack of proper infrastructure in the streets and insufficient building installations (Van Huyck \& Hornung, 1963, p. 13). However, the Hisarönü Neighborhood and its housing have the necessary infrastructure established during the early Republican period (and afterwards) which can be easily altered to improve these deficiencies.

The first step of a conservation project starts with the support of the state, local government, public institutions and private collaborators and investors. The state has the authority to expropriate; this means the historic site can be purchased by the state for temporary protection and then returned to their owners. In this way, the state, working with the professionals, can take initiatives to improve public areas, renew streets and sidewalks, maintain the infrastructure and plumbing of the neighborhood, define (vehicle) parking areas and, if necessary, propose and construct new public service buildings such as schools (Van Huyck and Hornung, 1963, p. 16). The contribution of such investments will encourage the owners and users to keep the historic buildings in constant maintenance.

In this study, the 'language of the city' is approached via an analogy of a neighborhood and its buildings as living organisms capable of narratives. Consequently, the Hisarönü Neighborhood from the 1920s' Ankara is analyzed via its narrative on past and recent history to signify its historical importance and commemorative value while drawing attention to the inevitable loss of its memory if left abandoned and neglected.

\section{Kaynakça/References}

Abu-Lughod, L.ve Lutz, C. A. (1990). Introduction: emotion, discourse, and the politics of everyday life. C. A. Lutz ve L. Abu-Lughod (Der.). Language and the politics of emotion içinde (s.1-23). New York: Cambridge University Press. 
Akgün, S. K. (2000). Kurtuluş savaşı'nın mekânsal stratejisi ve Ankara'nın başkent seçilmesi kararı. A. T. Yavuz (Der.) Tarih içinde Ankara içinde (s. 221-232). Ankara: TBMM Basımevi.

Aktüre, S. (2001). 1890'dan 1930'a Ankara'da günlük yaşam. Y. Yavuz (Der.) Tarih içinde Ankara II içinde (ss. 35-74). Ankara: ODTÜ Mimarlık Fakültesi Yayınları.

Aslanoğlu, İ. (2010). Erken cumhuriyet dönemi mimarlığı (1923-1938). İstanbul: Bilge Kültür Sanat.

Aydın, S., Emiroğlu, K., Türkoğlu, Ö. ve Özsoy, E.D. (2005). Küçük asya'nın bin yüzü: Ankara. Ankara: Dost Kitabevi Yayınları.

Basa, İ. (2000). Linguistic discourse in architecture (Yayınlanmamış doktora tezi). ODTÜ, Ankara.

Bertram, C. (2004). Housing the symbolic universe in early republican Turkey: Architecture, memory, and the felt real. E. Bastea (Der.) Memory and architecture içinde (ss. 165-190). New Mexico: University of New Mexico Press.

Birinci, A. (Der.) (2009). Refik halid karay, Ankara. İstanbul, İnkılap Yayıncılık.

Bozdoğan, S. (2012). Modernizm ve ulusun inşast: Erken cumhuriyet Türkiyesi'nde mimari kültür. (T. Birkan, Çev.). İstanbul: Metis Yayınları. (Orijinal eserin yayın tarihi 2001).

Cengizkan, A. (2002). Modernin saati: 20. yüzyılda modernleşme ve demokratikleşme pratiğinde mimarlar, kamusal mekân ve konut mimarlığı. Ankara: Mimarlar Derneği, Boyut Yayın Grubu.

Cengizkan, A. (2004). Ankara'nın ilk planı: 1924-25 Lörcher planı. Ankara: Ankara Enstitüsü Vakfı.

Colean, M. L. (1953). Renewing our cities. New York: The Twentieth Century Fund.

De Certeau, M.; Giard, L.; Mayol, P. (2009). Gündelik hayatın keşfi; II, konut, mutfak işleri. (Ç. Eroğlu ve E. Ataçay, Çev.). Ankara: Dost Kitabevi Yayınları. (Orijinal eserin yayın tarihi 1990).

De la Torre, M.; MacLean M. G. H.; Mason, R. ve Myers, D. (2005). Heritage values in site management, four case studies. Marta de la Torre (Der.). Canada: Getty Publications.

Dobby, A. (1978). Conservation and planning. London: The Anchor Press.

Google Earth (2020). Hisarönü. https://www.google.com/earth/ adresinden erişilmiştir.

Halbwachs, M. (2017). Kolektif hafiza. (B. Barış, Çev.) Ankara: Heretik Yayınlanı (Orijinal eserin yayın tarihi 1925).

Harvey, D. (2006). Sosyal adalet ve şehir. (M. Moralı, Çev.). İstanbul: Metis Yayıncılık. (Orijinal eserin yayın tarihi 1973)

İ.B.B. Atatürk Kitaplığı (1928). Işıklar. [Fotoğraf] Sayısal Arşiv ve e-Kaynaklar. Kartpostal Arşivi (Krt_009612).

Kuruyazıcı, H. (2008). Osmanlı'dan cumhuriyet'e bir mimar: Arif Hikmet Koyunoğlu, anılar, yazılar, mektuplar, belgeler. İstanbul: Yapı Kredi Yayınları. 
Lefebvre, H. (2010). Gündelik hayatın eleştirisi III. (I. Ergüden, Çev.) İstanbul: Sel Yayıncılık (Orijinal eserin yayın tarihi 1981).

Mayol, P. (2009). I. kısım - konut. De Certeau, M.; Giard, L.; Mayol, P. (Der.) Gündelik hayatın keşfi; II, konut, mutfak işleri içinde (s. 29-162). (Ç. Eroğlu ve E. Ataçay, Çev.). Ankara: Dost Kitabevi Yayınları. (Orijinal eserin yayın tarihi 1990).

Nalbantoğlu, G. (2000). 1928-1946 döneminde Ankara'da yapılan konutların mimari değerlendirilmesi. A. T. Yavuz (Der.) Tarih içinde Ankara içinde (s.253-270). Ankara: T.B.M.M Basımevi.

Nora, P. (2006). Hafiza mekânları. (M. E. Özcan, Çev.). Ankara: Dost Kitabevi Yayınları. (Orijinal eserin yayın tarihi 1974).

Rey, A. (1995). Essays on terminology. Philadelphia: John Benjamins Pub.

Sarıoğlu, M.(2001). "Ankara” bir modernleşme öyküsü (1919-1945). Ankara: T.C. Kültür Bakanlığı, Kültür Eserleri Dizgisi/290.

Sawyer, R. K. (2002). A discourse on discourse: an archeological history of an intellectual concept. Cultural Studies, 16(3), 433-356.

Snazzy Maps. (2020). Hisarönü. https://snazzymaps.com/style/24088/map-withoutlabels adresinden erişilmiştir.

Şahin Güçhan, N. (2001). 16-19 yy. nüfus tahminlerine göre Osmanlı Ankara'sında mahallelerin değişim süreçleri üzerine bir deneme. Y. Yavuz (Der.). Tarih içinde Ankara II içinde (ss.123-154). Ankara: ODTÜ Mimarlık Fakültesi Yayınları.

Şenol-Cantek, L. F. (2011). "Yaban"lar ve yerliler, başkent olma sürecinde Ankara. İstanbul: İletişim Yayınları.

Tankut, G. (2000). Jansen planı uygulama sorunları ve cumhuriyet demokrasisinin kent planına yaklaşımı. A. T. Yavuz (Der.). Tarih içinde Ankara içinde (ss.301-316). Ankara: TBMM Basımevi.

Tekeli, İ. (2006). Kent tarihi yazımı konusunda yeni bir paradigma önerisi. T. Şenyapılı (Der.). 'Cumhuriyet' in 'Ankara'sı içinde (ss. 2-24). Ankara: ODTÜ Yayıncılık.

Weber, M. (2000). Şehir: Modern kentin oluşumu. Don Martindale \& Gertrud Neuwirth (Der). (M. Ceylan (Çev.). İstanbul: Bakış Kitaplığı. (Orijinal eserin yayın tarihi 1960).

Van Huyck, A. P. ve Hornung, J. (1963). The citizen's guide to urban renewal. New Jersey: Chandler-Davis Publishing Company.

VEKAM. (t.y.). Konya. [Fotoğraf]. Fotoğraf ve kartpostal arşivi (2940). Ankara: Vehbi Koç Ankara Araştırmaları Uygulama ve Araştırma Merkezi.

Yavuz, Y. (2000). 1923-1928 Ankara'sında konut sorunu ve konut gelişmesi. A. T. Yavuz (Der.) Tarih içinde Ankara içinde (s.233-253). Ankara: TBMM Basımevi 